\title{
Nursing Innovations: Medication Administration Errors and Safety
}

\author{
Ragaa Gasim Ahmed Mohmmed ${ }^{1}$, Abeer El-Said Hassane El-sol ${ }^{2}$ \\ ${ }^{I}$ (Assistant professor of Pediatric Nursing, Faculty of Applied Medical Sciences, Nursing Department, Al-Baha \\ University, Saudi-Arabia) \\ ${ }^{2}$ (Lecturer of Medical-Surgical Nursing, Medical Surgical Department, Faculty of Nursing, Shibin Elkom, \\ Menoufia University, Egypt)
}

\begin{abstract}
Errors are an integral part of human life. Many errors originate from the natural process of cognitive and behavioral adaptations which develop the correct behavioral skills. Giving medicine is probably one of the most critical duties of nurses since the resulting errors may have unintended, serious consequences for the patient, medication errors are a major problem in nursing since most cases of medication errors are not reported by nurses it is also the main component of nursing performance and has a prominent role in patient safety. Medication errors can significantly affect patient safety and treatment costs and result in hazards for patients and their families. Medication errors are among the most common health threatening mistakes that affect patient care. Such mistakes are considered as a global problem which increases mortality rates, length of hospital stay, and related costs. Medication safety aims at the reduction of medication error rates, their earlier identification before the patient gets harmed and their timely treatment. Preventive strategies of medication errors include the standardization and the simplification of medical procedures and others. Nurses' vigilance and adoption of precaution measures about medication errors are key factors for preventing medication errors.
\end{abstract}

Keywords: Medication administration error, Medication administration safety, Nursing innovation

Abbreviations: ME; Medication Error, MAE; Medication Administration Error, ICU; Intensive Care Unit, NPSA; National Patient Safety Agency, CALNOC; Collaborative Alliance for Nursing Outcomes, CPOE; Computerized Provider Order Entry, BC; Bar Coding, FDA; Food and Drug Administration, USP; United States Pharmacopeia, NDC; National Drug Code; E-prescribing; Electronic Prescribing, EPR; Electronic Prescription Record, EMM; Electronic Medication Management, DUR; Drug Utilization Reviews

\section{Introduction}

The medication administration to patients is a compound procedure assumed by properly competent nurses. The mistake of drug administration may occur in any one of five process stages. These errors may affect patients in terms of morbidity, mortality, adverse drug events, increased extent of patient hospitalization stay and also rises budgets for clinicians and healthcare systems. The source of these errors may be the nurses' interruptions have been happening during the medications preparation and administration. Many interventions planned to reduce these errors as allocated a specific room for medication preparation to eliminate external stimuli, put signs of interruption-free areas. Other methods approved their effects as evidence-based practices in health care, as the unit dose system, IV admixture, CPOE, and BCMA. The nurses must ensure that correct procedures are followed and ensure the patient receives the correct medication by applying of eight rights as the right dose will give at the right time and right route [1].

Medication error is any stoppable occurrence that may cause or lead to incorrect medication use or patient harm while the medication is in the control of the health professional, patient, or consumer [2,3]. Medication error (ME) is a mistake can happen in any stage of five stages of drug administering process as the prescribing, verifying, preparing, administering and monitoring of drug, ME is the single most preventable cause of patient hurt [4]. ME adjusted by the hospital's health care systems as nursing staff before getting the patient. Inappropriately, in gathering these documents, it was not possible to analyze out these alterations [5]. The accountability of medication administration, safety shared between nurses and health care institute built on the goals of the Institute for Safe Medication Practices, which occurred by approving necessary "7 rights" of medication administration: right patient, right drug, right dose, right time, right route, right education and the right documentation. The most common type of medication error at this hospital is the wrong time represented $30 \%$ from errors $[6]$.

\subsection{Distributional epidemiology of medication administration error}

Medication administration errors (MAE) are a significant global concern and can cause serious medical consequences for patients. The majority of MAE involved either dose omissions (42\%) or wrong time 
administration. Little is known about medication errors in Middle Eastern countries [7]. The Institute of Medicine estimates that, on average, hospitalized patients are subject to at least one medication error per day. The National Patient Safety Agency (NPSA) of UK revealed that, MAE is common, and this occurs in $50 \%$ of all drug medication administrations in hospitals. In the United State, MAE occurs in 5 to $20 \%$ of all drug administrations, costing the healthcare system an extra $\$ 380$ million and estimated to harm at least 1.5 million patients per year, with about 400,000 preventable adverse events, medication errors have been estimated to account for 7,000 deaths per year [8].

Australian Commission on Safety and Quality in Health Care estimates that medication administration errors occur in 5-10\% of all medicines administered, signaling an immense safety and quality issue. In England, medication administration error rates reportedly occur in 3-8 \% of all hospital admissions, MAE in East Africa is common and the error rate ranges from 9.4 to $80 \%$ of all medication administrations, the prevalence of MAE in Jimma, Ethiopia within the intensive care unit (ICU) and pediatric ward showed 51.8 and $90.8 \%$, respectively [9].

The Institute of Medicine Committee on Identifying and Preventing Medication Errors estimates that at least 1.5 million preventable adverse medication events occur annually in the United State, warning that this is likely to significantly underestimate the problem [10].

1.2 Routes of medication administration (Advantages \& Disadvantages): Table (1) [11].

\begin{tabular}{|c|c|c|}
\hline Route & Advantages & Disadvantages \\
\hline Oral & $\begin{array}{l}\text { Easy } \\
\text { Preferred by patients "Slow-release" } \\
\text { preparations may be available to extend } \\
\text { duration of action } \\
\text { Drugs can be formulated in such a way as to } \\
\text { protect them from digestive enzymes, acid, } \\
\text { etc. }\end{array}$ & $\begin{array}{l}\text { Local effect - Antibiotics may kill } \\
\text { normal gut flora and allow an } \\
\text { overgrowth of fungal varieties. Thus, } \\
\text { antifungal agent may be included with } \\
\text { an antibiotic. } \\
\text { Unconscious patient - Patient must be } \\
\text { able to swallow solid dosage forms. } \\
\text { Liquids may be given by tube. } \\
\text { Most orally administered drugs are } \\
\text { absorbed slowly } \\
\text { Unpredictable absorption due to } \\
\text { degradation by stomach acid and } \\
\text { enzymes }\end{array}$ \\
\hline $\begin{array}{l}\text { Buccal and } \\
\text { Sublingual }\end{array}$ & $\begin{array}{l}\text { - First pass-the liver is bypassed thus there is } \\
\text { no loss of drug by first pass effect for buccal } \\
\text { or sublingual administration. Bioavailability } \\
\text { is higher. } \\
\text { Quick absorption due to the good blood } \\
\text { supply to the area of absorption is usually } \\
\text { quite rapid, especially for drugs with good } \\
\text { lipid solubility. } \\
\text { Drug constancy - pH in mouth relatively } \\
\text { neutral (Stomach- acidic). Thus, a drug may } \\
\text { be more stable. }\end{array}$ & $\begin{array}{l}\text { - Holding the dose in the mouth is } \\
\text { inconvenient. If any part of the dose is } \\
\text { swallowed that portion must be treated } \\
\text { as an oral dose and subject to first pass } \\
\text { metabolism. } \\
\text { - Usually more suitable for drugs with } \\
\text { small doses. } \\
\text { - A drug test may need to be masked. }\end{array}$ \\
\hline Rectal & $\begin{array}{l}\text { Good absorption - the haemorrhoidal veins } \\
\text { drain directly into the inferior vena cava, } \\
\text { avoiding hepatic first pass metabolism } \\
\text { Useful for patients unable to take drugs } \\
\text { orally or with younger children. }\end{array}$ & 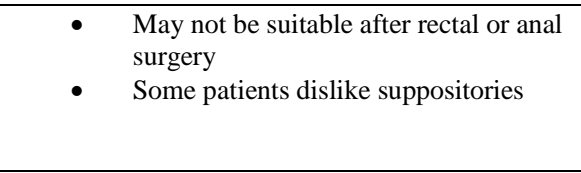 \\
\hline $\begin{array}{l}\text { Subcutaneous } \\
\text { (SC) }\end{array}$ & $\begin{array}{l}\text { - Can be given by patient, e.g. in the case of } \\
\text { insulin. } \\
\text { Absorption can be fast from aqueous } \\
\text { solution but slower with depot formulations. } \\
\text { Absorption is usually complete. } \\
\text { Improved by massage or heat. } \\
\text { Vasoconstrictor may be added to reduce the } \\
\text { absorption of a local anesthetic agent, } \\
\text { thereby prolonging its effect at the site of } \\
\text { interest. }\end{array}$ & $\begin{array}{l}\text { Can be painful. Finding suitable sites } \\
\text { for repeat injection can be a problem. } \\
\text { Irritant drugs can cause local tissue } \\
\text { damage. } \\
\text { Maximum of } 2 \mathrm{ml} \text { injection, thus often } \\
\text { small doses limit use. }\end{array}$ \\
\hline $\begin{array}{l}\text { Intramuscular } \\
\text { (IM) }\end{array}$ & $\begin{array}{l}\text { Larger volume than SC can be given by IM. } \\
\text { They may be easier to administer than IV } \\
\text { injections. } \\
\text { A depot or sustained release effect is } \\
\text { possible with IM injections, e.g. procaine } \\
\text { penicillin. }\end{array}$ & $\begin{array}{l}\text { - Trained personnel required for } \\
\text { injections. The site of injection will } \\
\text { influence the absorption; generally the } \\
\text { deltoid muscle provides faster and more } \\
\text { complete absorption. } \\
\text { Absorption can be rapid from aqueous } \\
\text { solution. Absorption is sometimes } \\
\text { erratic, especially for poorly soluble } \\
\text { drugs, e.g. diazepam, phenytoin. The } \\
\text { solvent maybe absorbed faster than the } \\
\text { drug causing precipitation of the drug at }\end{array}$ \\
\hline
\end{tabular}




\begin{tabular}{|c|c|c|}
\hline & & $\begin{array}{l}\text { the site of injection. } \\
\text { - } \quad \text { Irritating drug may be painful }\end{array}$ \\
\hline Intravenous & $\begin{array}{c}-\quad \text { Dependable and reproducible effects } \\
\text { Entire administered dose reaches the } \\
\text { systemic circulation immediately - the } \\
\text { dose can be accurately titrated against response }\end{array}$ & $\begin{array}{l}\text { Suitable vein - It may be difficult to } \\
\text { find a suitable vein. There may be some } \\
\text { tissue damage at the site of injection. } \\
\text { May be toxic - Because of the rapid } \\
\text { response, toxicity can be a problem with } \\
\text { rapid drug administrations. For drugs } \\
\text { where this is a particular problem the } \\
\text { dose should be given as an infusion, } \\
\text { monitoring for toxicity. } \\
\text { Requires trained personnel - Trained } \\
\text { personnel are required to give } \\
\text { intravenous injections. } \\
\text { Expensive - Sterility, pyrogen testing } \\
\text { and larger volume of solvent means } \\
\text { greater cost of preparation, transport } \\
\text { and storage. }\end{array}$ \\
\hline Topical & $\begin{array}{ll} & \text { Easy } \\
- & \text { Noninvasive } \\
- & \text { High levels of patient satisfaction }\end{array}$ & $\begin{array}{l}\text { Most drugs have a high molecular } \\
\text { weight and are poorly lipid soluble, so } \\
\text { are not absorbed via skin or mucous } \\
\text { membranes } \\
\text { - } \quad \text { Very slow absorption }\end{array}$ \\
\hline Inhaled & $\begin{array}{l}\text { Very rapid absorption due to the huge } \\
\text { surface area of the respiratory endothelium } \\
\text { Bronchodilators and inhaled steroids can be } \\
\text { targeted to lungs with low levels of systemic } \\
\text { absorption }\end{array}$ & $\begin{array}{l}\text { Bioavailability depends on the patient's } \\
\text { inhaler technique and the size of drug } \\
\text { particles generated by the delivery } \\
\text { technique }\end{array}$ \\
\hline $\begin{array}{l}\text { Topical or } \\
\text { Transdermal }\end{array}$ & $\begin{array}{l}\text { - Generally absorption is quite slow. } \\
\text { Transdermal patches can provide prolonged } \\
\text { or controlled (iontophoresis) drug delivery. } \\
\text { Local effect - ear drops, eye drops or } \\
\text { ointment, antiseptic creams and ointments, } \\
\text { sunscreens, callous removal products, etc. } \\
\text { Systemic effect - e.g., nitroglycerin } \\
\text { ointment. }\end{array}$ & $\begin{array}{l}\text { - An occlusive dressing may be used to } \\
\text { improve absorption. } \\
\text { May be a real problem in handling toxic } \\
\text { materials in the laboratory or pharmacy. } \\
\text { This can also be a serious problem with } \\
\text { garden chemicals. } \\
\text { There may be some skin irritation. Drug } \\
\text { absorption will vary by site of } \\
\text { administration, skin condition, age and } \\
\text { gender. }\end{array}$ \\
\hline \multicolumn{3}{|c|}{$\begin{array}{l}\text { Other routes of administration include: nasal, some systemic absorption has been demonstrated for Propranolol and some low } \\
\text { dose hormones; intra-arterial for cancer chemotherapy to maximize drug concentrations at the tumor site; and intrathecal } \\
\text { directly into the cerebro-spinal fluid. Others routes with limited systemic absorption, but with local utility include topical, } \\
\text { ocular, oral, vaginal, and urethral and intrasynovial [11]. }\end{array}$} \\
\hline
\end{tabular}

\subsection{Severity levels of medication error}

Medication errors are costly and at times hurtful to patients.

Level 0-No medication error happened.

Level 1-An error happened without patient harm.

Level 2-An error happened; which lead to the necessity for patient monitoring, without alteration in hemodynamic status as (vital signs) and no patient impairment.

Level 3-An error arose that caused the need for greater than before patient monitoring with a change in vital signs, but no ultimate patient harm, or any error that resulted in the need for increased laboratory follow up.

Level 4-An error happened that lead to the need for treatment with another drug or prolonged duration of hospital admission or that affected patient participation in an investigational drug study.

Level 5-An error happened; this error causes a permanent patient's impairment.

Level 6-An error happened; which lead to patient death [12].

1.4 Medication Error Reporting and Prevention Error Category Index: Table (2) [13].

\begin{tabular}{|c|c|c|c|c|}
\hline Error category & Error occurrence & Reached patient & Associated harm & Necessary measures \\
\hline A & Possible & No & No & No \\
\hline B & Yes & No & No & No \\
\hline C & Yes & Yes & No & Monitoring \\
\hline D & Yes & Yes & Temporary & Medical intervention \\
\hline E & Yes & Yes & Permanent & hospital stay \\
\hline F & Yes & Yes & Possibility of death & Vital support intervention \\
\hline G & Yes & Yes & Death & \\
\hline H & Yes & Yes & &
\end{tabular}


1.5 List of abbreviations used in medical prescriptions: Table 3 [14].

\begin{tabular}{|c|c|c|}
\hline No & Abbreviation & Meaning \\
\hline 1. & aa & Of each \\
\hline 2. & AAA & Apply to affected area \\
\hline 3. & a.c. & Before meals \\
\hline 4. & a.d & Right ear \\
\hline 5. & a.m. & Morning, before noon \\
\hline 6. & amp & Ampule \\
\hline 7. & amt & Amount \\
\hline 8. & a.l., a.s. & Left ear \\
\hline 9. & a.u. & Both ears \\
\hline 10. & BDS/bds/b.i.d./b.d. & Twice daily \\
\hline 11. & Bis & Twice \\
\hline 12. & B.S. & Blood sugar \\
\hline 13. & b.t. & Bedtime \\
\hline 14. & cap., caps & Capsule \\
\hline 15. & IM & Intramuscular \\
\hline 16. & ID\& SC & Intradermal\& Subcutaneous \\
\hline 17. & IP & Intraperitoneal \\
\hline 18. & IV & Intravenous \\
\hline 19. & IVP & Intravenous push \\
\hline 20. & o.d. & Right eye \\
\hline 21. & o.s. & Left eye \\
\hline 22. & o.u. & Both eyes \\
\hline 23. & p.c. & After meals \\
\hline 24. & p.m. & Evening or afternoon \\
\hline 25. & p.o. & By mouth or orally \\
\hline 26. & p.r. PR & By rectum \\
\hline 27. & PRN, prn & As needed \\
\hline 28. & q.a.d. & Every other day \\
\hline 29. & q.d.s. or q.i.d. & Four times a day \\
\hline 30. & q.h.s. & Every night at bedtime \\
\hline 31. & s.i.d/SID & Once a day \\
\hline 32. & SL & Sublingually, under the tongue \\
\hline 33. & stat & Immediately \\
\hline 34. & supp & Suppository \\
\hline 35. & susp & Suspension \\
\hline 36. & syr & Syrup \\
\hline 37. & t.i.d. & Three times a day \\
\hline 38. & t.i.w. & Three times a week \\
\hline 39. & cr., crm & Cream \\
\hline 40. & ung & Ointment \\
\hline
\end{tabular}

\subsection{Medication administration process phases}

Medication administration procedure in a method that permitted the provision of existing information on common foundations of mistakes as well as successful methods to avoid such errors with a certain emphasis on electronic tools. Medication administration is a rather compound and difficult duty and depending on the location and co-medication an excessive different errors type; which may occur. These errors due to numerous kinds of obstacles and interruptions, phone calls, other patients' needs, and not working equipment may are source of medication errors in drug handling and administration are diverse and frequent, and in many cases not caused by the patient him/herself, but by family members or nurses. The medication administration process consists of a complex five phase process: (a) prescribing, (b) verifying, (c) preparing/dispensing (d) administering, and (e) monitoring. A ME can arise in all of these phases. Rates of medication errors vary, depending on the recognition way used. One-third of all MEs causing harm to patients in hospitals happen in the medication preparation and administration phase, which is predominantly a nursing activity [15].

\subsection{Components of a Medication Order}

Medications should be prescribed as direct orders; that is, the medication is ordered for a specific client. The approved prescriber is predictable to document their own medication orders. A complete medication order (prescription) includes:

- Full name of the client

- The date

- Name of the medication

- Drug strength, if applicable

- Dosage, if applicable 
- Route of administration

- Frequency, and in some cases the length of time the drug is to be administered

- Prescriber's name, signature and designation

- Reason/purpose and

- Monitoring as required [16].

1.8 Types of medication error: Table 4 [17,18].

\begin{tabular}{|c|c|}
\hline Type & Definition \\
\hline Prescribing error & Is the improper choice of drug for a patient \\
\hline Dispensing errors & $\begin{array}{l}\text { The distributing process from the receiving of the prescription in the } \\
\text { pharmacy to the supply of a dispensed medication to the patient. }\end{array}$ \\
\hline Administration errors & $\begin{array}{l}\text { Running errors occur when a difference occurs between the drugs received } \\
\text { by the patient and the drug therapy proposed by the prescriber. }\end{array}$ \\
\hline Omission error & $\begin{array}{l}\text { The failure to administer an ordered dose to a patient before the next } \\
\text { scheduled dose, if any. Assuming there is no prescribing error. }\end{array}$ \\
\hline Timing error & $\begin{array}{l}\text { Administration of medication outside a predefined time interval from its } \\
\text { scheduled administration time }\end{array}$ \\
\hline Dosing error & $\begin{array}{l}\text { Administration to the patient of medication not authorized by a legitimate } \\
\text { prescriber for the patient. This would include, for example, a wrong drug, a } \\
\text { dose given to the wrong patient, unordered drugs, and doses given outside a } \\
\text { stated set of clinical guidelines or protocols. }\end{array}$ \\
\hline $\begin{array}{l}\text { Route of administration } \\
\text { error }\end{array}$ & Incorrect procedure or wrong technique in the administration of a drug. (1) \\
\hline Monitoring error & $\begin{array}{l}\text { A monitoring error occurs when a prescribed medicine is not monitored in } \\
\text { the way which would be considered acceptable in routine general practice. }\end{array}$ \\
\hline $\begin{array}{l}\text { Unauthorized or } \\
\text { illegitimate drug error }\end{array}$ & $\begin{array}{l}\text { Dispensing or administration to the patient of medication not authorized by } \\
\text { a legitimate prescriber. }\end{array}$ \\
\hline Dosage form error & $\begin{array}{l}\text { Dispensing or administration to the patient of a drug product in a different } \\
\text { dosage form than that ordered by the prescriber. }\end{array}$ \\
\hline Drug preparation error & $\begin{array}{l}\text { Drug product incorrectly formulated or manipulated before dispensing or } \\
\text { administration. }\end{array}$ \\
\hline $\begin{array}{l}\text { Administration } \\
\text { technique error }\end{array}$ & $\begin{array}{l}\text { Inappropriate procedure or improper technique in the administration of a } \\
\text { drug other than wrong route. }\end{array}$ \\
\hline Deteriorated drug error & $\begin{array}{l}\text { Dispensing or administration of a drug that has expired or for which the } \\
\text { physical or chemical dosage-form integrity has been compromised. }\end{array}$ \\
\hline Compliance error & $\begin{array}{l}\text { Incorrect patient behavior regarding adherence to a prescribed medication } \\
\text { regimen. ( } 2 \text { ) }\end{array}$ \\
\hline
\end{tabular}

\subsection{Contributing Factors to Medication Errors}

There are numerous reasons can cause medication errors as interruptions to nurses were considerably accompanying with more medication errors and more severe errors [19,20].

The most extensive interruptions during medication administration are phone calls. Different types of phone calls are as call lights from patient rooms, calls from providers or other services, and calls from outside the hospital. Unit clerks tend to forward or page for nurses right away, whether or not the reason for the call truly requires a nurse [21].

Other causes are work shift (higher error rates typically occur during the day shift), inexperienced and incompetently trained staff in dose calculation, certain patient as geriatrics, pediatrics, and oncology need special nursing care, sometimes patient take different types of medication, environmental factors (lighting, noise), staff amount of work and bodily feelings of fatigue, sleepiness lack, illness and overall distress, poor ways of communication among health-care team, variable dosage form, wrong drug storage, poor handwriting, oral orders, weakness of actual rules and procedures [22].

The most common causes of ME are unclear strength name on labels or in packaging; drug product nomenclature (look-alike or sound-alike names, use of lettered or numbered prefixes and suffixes in drug names); equipment failure or malfunction; illegible handwriting; improper transcription; incorrect dose calculation; inadequately trained personnel; inappropriate abbreviations used in prescribing; labeling errors; excessive workload; gaps in individual performance; and medication unavailable [23]. 


\section{The Seven Essential Rights Of Medication Administration}

2.1 Right patient: The right medication must be administered to the patient for whom it is prescribed. Administering a medication to the wrong patient is, however, a common error.

2.2 Right drug: Research has shown that one third of medication errors involved the patient being given the wrong medication. Nurses are not legally qualified to prescribe medications, but if they are hesitant of the medication name prescribed (or think it is the wrong one), they should not administer it before checking with the prescriber.

2.3 Right route: Nurses are only allowed to administer medications by the route prescribed, though sometimes the prescriber may give a choice (IV/PO). The nurse must understand the differences between these routes such as the rate of absorption or onset of action. Nurses do have the choice of the form of medication to be administered (e.g. Tablets, syrup). The form of the medication though must be right for the route of administration [24].

2.4 Right time: Medications must be administered at the correct time to ensure therapeutic serum levels. Administering the medication at the wrong time is therefore one type of error.

2.5 Right dose: Most nurses do not prescribe medications. The rare exceptions are nurse prescribers, who are allowed to prescribe in limited circumstances, with the relevant qualifications. In clinical practice, nurses must only administer the dose prescribed by the medical officer.

2.6 Right education: Patients must receive on-going education from physicians, pharmacists and the nursing staff about the brand and generic names of medications they are receiving, their indications, and doses, expected and possible adverse effects, drug or food interactions, and how to protect themselves from errors. Patients can play a vital role in preventing medication errors when they have been encouraged to ask questions and seek answers about their medications [25].

2.7 Right documentation: When a nurse administers a medication, he or she must document in the medication administration chart. This provides evidence that the medication has been administered to the patient. Documentation the medication in a chart before the medication has been administered is a wrong, because of the patient may refuse to take this medication or, in some cases, forget to take them. Similarly, failing to sign when a medication has been administered creates the risk that another nurse may assume that it has not been administered, and repeat that dose [26].

\section{Nursing And Medication Administration Safety}

The nursing staff plays a key role in insuring the safety of patients because it provides direct assistance and care to the patient and family, composing the largest group of professionals in the health field in the world. There are many interventions to diminish medication administration errors and keep the patient safety during the process of medication administration. Patient safety is a problem encountered in the health field around the world. The Collaborative Alliance for Nursing Outcomes (CALNOC), is the nation's first registry dedicated to nursing sensitive measures at the unit level, it is a self-sustaining non-profit public benefit corporation with over 15 years' experience in advancing the safety and quality of patient care. CALNOC, stated that there are six manners, serious to safe medication administration: (1) Compare medication to ear at least twice, (2) Decrease disruptions_and interruptions, (3) Keep medication labeled throughout the process, (4) Check two patient identifiers, (5) Explain drug to patient as appropriate, (6) Chart directly after administration [27].

\section{Interventions To Minimize Medication Administration Errors}

Nurses should know the reasons of work disturbance and put plan to avoid and to reduce the patient risk. The effective plan for medication administration that could separate the medication preparation in special area, and put signal determine that this area should be free from interruption in addition to continuous health education for nursing and encourage for collaboration between nurses and how to use the time efficiently and restrict the number of visitors to minimize disturbance. Nurses staff can put accurate documentation of drugs and time of administration [28].

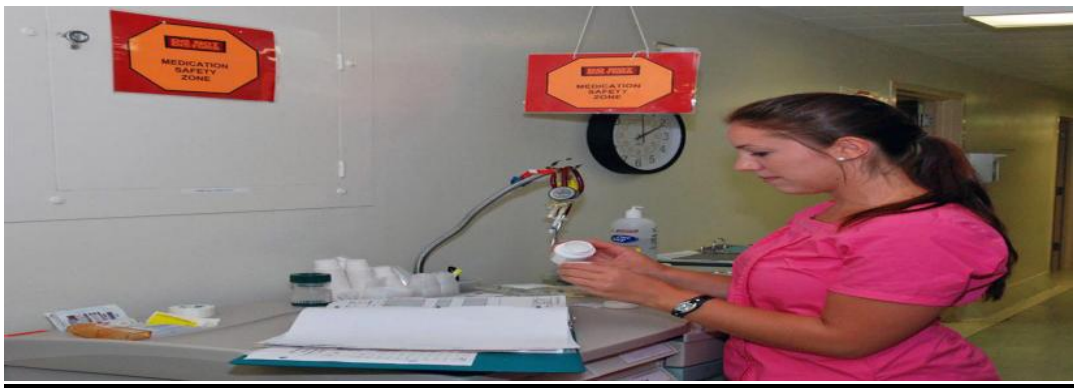

Fig 1: Minimizing the rate of interruptions during medication preparation $[28,29,30]$. 


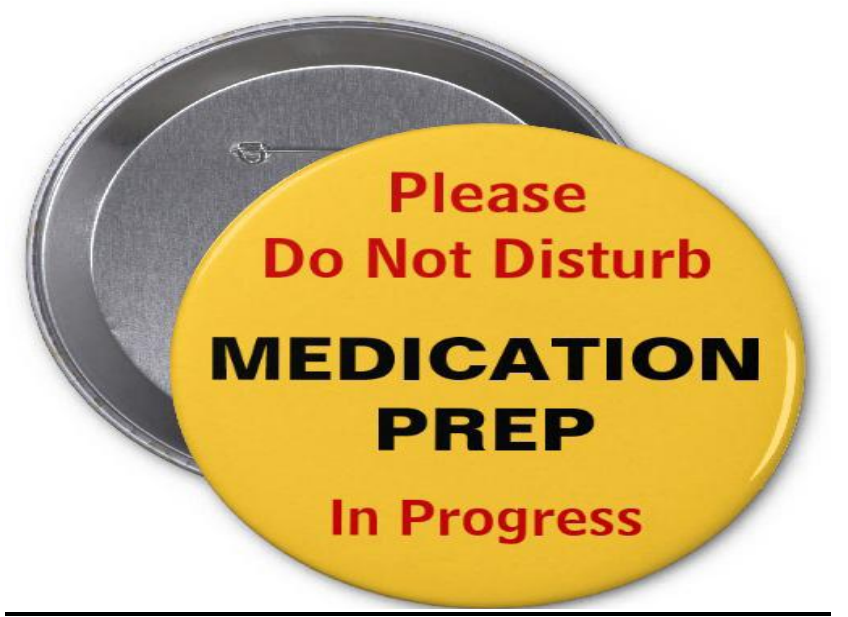

Fig 2: Decreasing the rate of interruptions during medication preparation $[28,29,30]$.

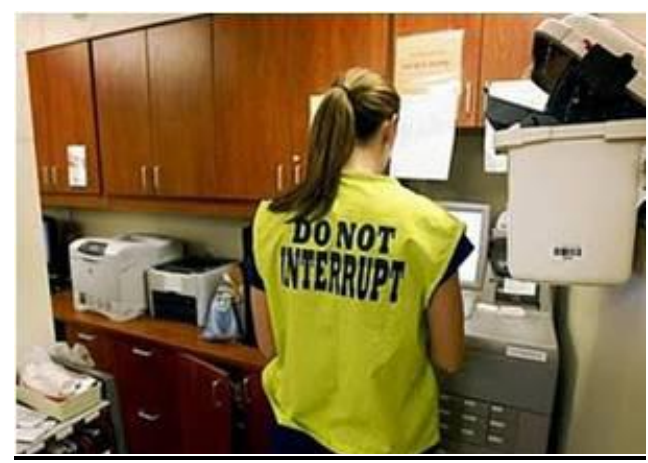

Fig 3: Diminishing the rate of interruptions during medication preparation [31,32].

The medication safety development by provide an adequate number of pharmacist and nurse; nurses work flow should be scheduled properly, adopt effective medication understanding strategies; implement appropriate technology, and foster a culture of responsibility that values quality improvement [33].

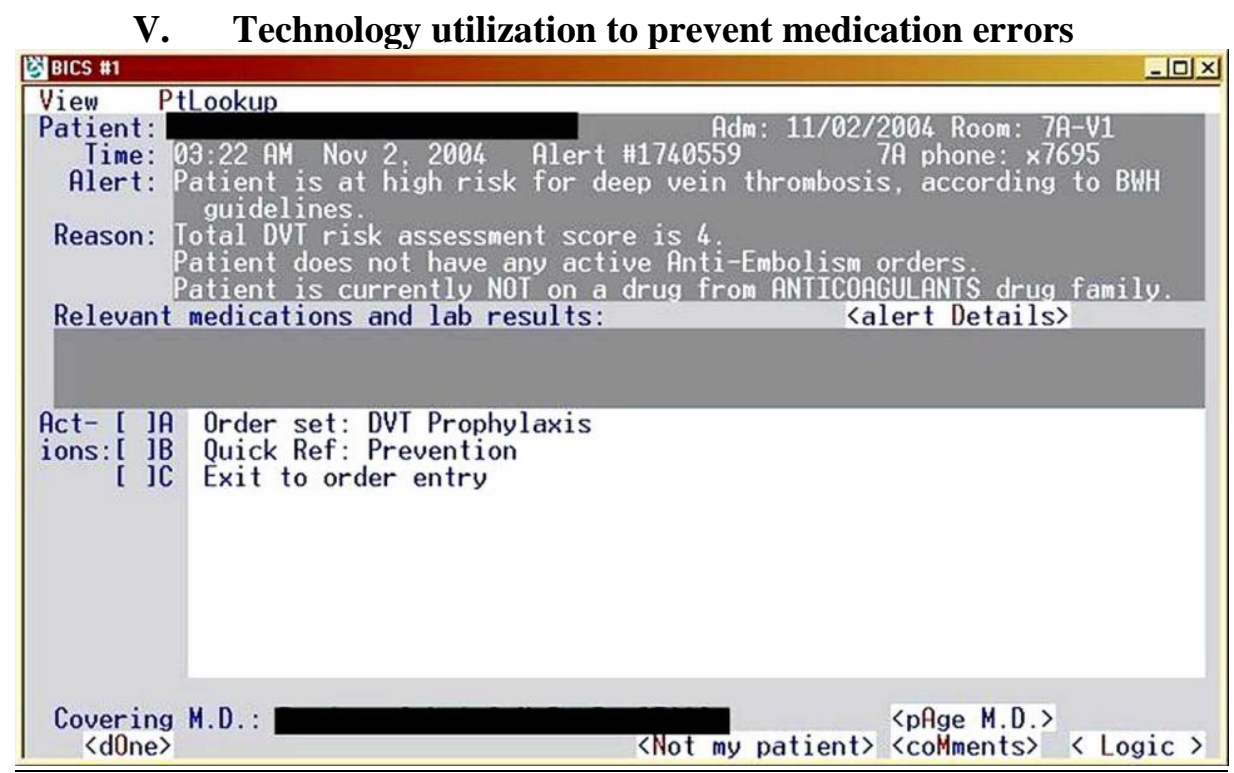

Fig 4: Computer alert for venous thromboembolism risk [34]. 


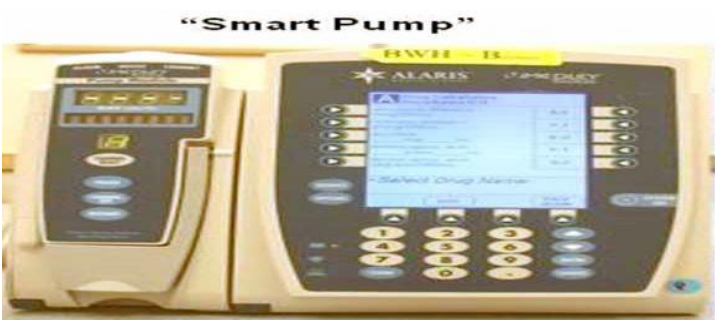

Incorrect Dose Entry A Guardrails Drug Libran

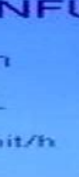

Fig 5: Smart pump drug libraries [34] zeoo umith.

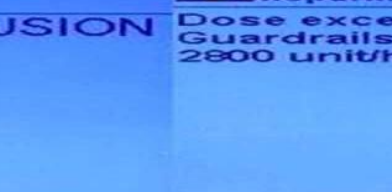

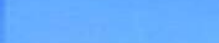

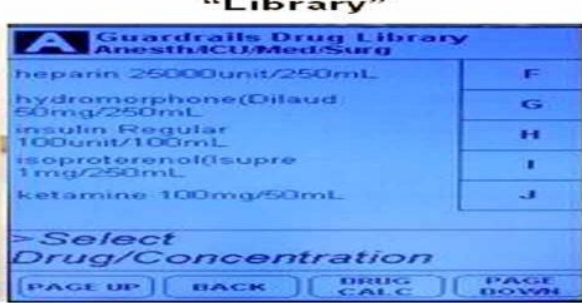

Dose Limit Alert A Guardrails Drug Liskory Dose exceeds the 


\section{Patient Role In Preventing Medication Errors}

Patients have a responsibility to prevent medication error by some instruction. The patient should : 1). Know the labels of drugs 2). Deliver and read the sheet witch wrote by pharmacists 3 ). Do not share your drug and drug of another patient 4). Do not use the drug out of date 5). Store your drug properly 6). Save drug away from children, and 7). Learn about drug and drug food interaction [36].

\section{Methods Of Medication Safety And Error Prevention}

The methods used to minimize medication error and enhanced medication safety approved by many studies and used by evidence based practice in many health care settings, as the unit dose system, IV admixture, CPOE, and BCMA.

\subsection{Unit dose system}

Is a system prepared by the hospital pharmacy for 24 hours to supply and distribute medication in a portable cart having a drawer for each patient [37]. Technology is not needed in the unit dose system. This method is very safer by using individual patient medication package, rather than requiring caregivers to take medicines from wholesale supplies to the patient individually. The advantages of dosage unit dispensing drugs are (1). Minimize the rate of medication errors. (2). Decrease in the price of drug-related activities. (3). More effective use of pharmacy and nursing staff, permitting more direct care of the patient by pharmacists and nurses. (4). Enhance general drug control and drug use observing. (5). Improve correctness, less nursing time at supply. The disadvantage of unit dose drug dispensing are (1). Timelier processing pharmacy and cost of equipment. (2). Needs enough space for storage (3). No charge investments to pharmacy. (4). Reduce nursing processing and capacity check [38].

\subsection{Intravenous admixture system}

Intravenous admixture system has been a preparation of the drug doses by individuals trained specifically for accurate medication preparation by labeling method for each patient for 24 hours. Hospital extent may also play a role. Small hospitals usually contain more intravenous contusions on the bed. The pharmacist is responsible for ensuring that complex sterile preparations are properly ready, labeled, kept, distributed and transported. Its advantages over other systems including: a) Decrease incidence medication errors occurrence; b) Minimize medication-related activities for nursing; c) Pharmacy and nursing personnel using are efficient d) Accurate medication monitoring; e) The medication inventories were decreased f) Reducing waste and embezzlement, g) Increased capacity to adapt to computerized procedures, and, h) And improve job satisfaction for health care workers [39].

\subsection{Use of technology innovation as:}

Bar coding is an electronic technology, which reduces drug error and increases patient safety measures with regard to administering medication through machine readable symbols ("bar codes") consider as a tool help in appropriate dose of medication for the right patient. Recently the amount of knowledge increased within bar code scanning technology. The NCCMERP recommends that the Food and Drug Administration (FDA), the United States Pharmacopeia (USP), and pharmaceutical manufacturers work together to have the subsequent data fixed into a medication bar code:

- National Drug Code (NDC) amount which recognizes the unique drug, dosage method, and strength.

- Lot/Control/Batch number, which assists in patient of product recalls.

- Expiration date, assured that the patient doesn't use expired medication [40].

\subsubsection{Electronic prescription record:}

The electronic prescription record contains all data required to legally fill, name, submit and / or apply for a treatment. Pharmacists use the registry as a tool to reduce drug errors by guarding against drug interactions, duplicate treatments and drug contraindications. The EPR can also help in improving patient outcome and reduce drug mistakes by pharmacists through monitoring and evaluating of use and by facilitating communication between healthcare providers. In a timely manner, managed health care systems will link needles with other medical records systems, allowing prescriptions to transfer prescriptions directly to the pharmacy of patient choice. The care of patients improved through the integration of the patient's entire pharmacy and medical record through a process of total patient management, including the decrease of medication mistakes [41].

\subsubsection{Electronic Medication Management (EMM) System:}

Medication administration error decreased by implementing an electronic drug management system (EMM) in the hospital by the (1) Precautions of medication administration (2) Interdisciplinary team engagement (3) Financial support 4) Accurate leadership structure (5) Assign senior medical staff to work on 
EMM (7) Scientific possibility for EMM should be perfect (8) Relations between the EMM system and other medical and organizational systems should be clear (9) Readiness of internet access (10) Providing EMM of technical organization supporting system (11) Incorporation with pharmacy dispensing systems and (12) Strategic plan should be tested and implemented. People who get benefit from EMM are medical staff; Nurses; and Pharmacists [42].

\subsubsection{Electronic drug}

The online Drug Utilization Review (DUR) was conducted by pharmacist due to the technology of the electronic prescription required. It allows the pharmacist to do prescription reviewing order at the time of filling to prevent potential patient drug-drug interaction, drug over-use and drug; under-use and drug sensitivity reaction, compare between patient record and pharmacist record to prevent and minimize error. An online DUR process includes the following: 1). Contraindication of drug regarding specific disease 2). Drug-drug interactions, 3). Drug dose, incorrect, 4). Duration of drug, 5). Drug hypersensitivity reaction [43].

\subsubsection{Automated medication dispensing:}

Automated medication dispensing systems are now widely used as a fewer work hard system of dispensing medications. Automated pharmacy dispensing systems are more effective for accomplishing the pharmacists tasks that require boring, repetitive motions, and confident concentration and reliable record keeping, which can all lead to medication dispensing errors. The appropriate utilization of automated medication dispensing is minimized medication error and the utilization of the bar coding technology to ensure the right drug, and dosage form is one of automated dispensing systems [44].

\section{Conclusion}

The majority of the studies concluded there is a high prevalence of medication administration error. Each patient had at least one medication administration error. Documentation error was the most dominant type of error followed by technique and time error respectively. Organizational factors such as error reporting systems and routine checks could possibly help in handling the problem of medication errors. Also, increasing nurse staffing levels, minimizing distraction and interruptions during medication administration by decreasing overcrowding and by using no interruptions zones and "No-Talk" signage is recommended to overcome MAEs.

References

[1] Raban MZ, Lehnbom EC, and Westbrook JI. Evidence briefings on interventions to improve medication safety. Centre for Health Systems and Safety Research (Australian Commission on Safety and Quality in Health Care) 4(1) (2013)

[2] Jaleel Anne Arnado. Minimizing Avoidable Interruptions During Medication Administration. The University of San .i

.,Francisco USF Scholarship: a digital repository @ Gleeson Library| Geschke Center; (2014)

[2] About medication errors: what is a medication error? National Coordinating Council for Medication Error Reporting and Prevention.. Retrieved from http://www.nccmerp.org/aboutMedErrors.html

[3] Marian Smeulers, Lotte Verweij, Jolanda M. Maaskant, Monica de Boer, Paul Krediet, Els J. M. Nieveen van Dijkum, Hester and Vermeulen, "Quality Indicators for Safe Medication Preparation and Administration": A Systematic Review. Journal. Pone 10(4) (2015) : e0122695. Doi: 10.1371.0122695

[4] David C Radley, Melanie R Wasserman, Lauren EW Olsho, Sarah J Shoemaker, Mark D Spranca and Bethany Bradshaw. Reduction in medication errors in hospitals due to adoption of computerized provider order entry systems. $J$ Am Med Inform Assoc 2013; 20:470-476. Doi: 10.1136/amiajnl-2012-001241

[5] The five rights: A destination without a map. Institute for Safe Medication Practices. 2007 [cited 2014 July 30]. Available: http://www.ismp.org/newsletters/acutecare/articles/20070125.asp.

[6] Cuttler, S. Medication Error Reduction Plan Report. Collaborative Alliance for Nursing Outcomes:(2014)

[7] Senafikish Amsalu Feleke1, Muluadam Abebe Mulatu and Yeshaneh Seyoum Yesmaw :Medication administration error: magnitude and associated factors among nurses in Ethiopia; BMC Nursing 14(53)(2015)

[8] Zayed Alsulami \& Sharon Conroy \& Imti Choonara ; A systematic review of the literature; Medication errors in the Middle East countries: Eur J Clin Pharmacol (2013) 69:995-1008 DOI 10.1007/s00228-012-1435-y

[9] Alison M. Hutchinson, Anne E. Sales, Vanessa Brotto1 and Tracey K. Bucknall1,: Implementation of an audit with feedback knowledge translation intervention to promote medication error reporting in health care: a protocol; Implementation Science (2015) 10:70 DOI 10.1186/s13012-015-0260-y

[10] David W. A. Bourne; Routes of Drug Administration. PHAR 7633 Chapter 7 Available at: http://www.boomer.org/c/p4/c07/c07.html Bourne, D.W.A; . Pharmacy Math (2014) - Part 1, Apple iTunes Bookstore,

[11] Hartwig SC, Denger SD, Schneider PJ. A severity-indexed, incident-report based medication-error reporting program. Am J Hosp Pharm. (1991); 48:2611-6. Program. Am J Hosp Pharm. 1991; 48:2611-6.

[12] Gabriella Rejane dos Santos Dalmolin1, Eloni Terezinha Rotta, José Roberto Goldim. Medication errors: classification of seriousness, type, and of medications involved in the reports from a University Teaching Hospital. Brazilian Journal of Pharmaceutical Sciences . 49 (4) 2013

[13] Report actual and potential medication errors to the ISMP National Medication Errors Reporting Program (ISMP MERP) (2015) www.ismp.org.

[14] Elizabeth Manias, Allison Williams \& Danny Liew ; Interventions to reduce medication errors in adult intensive care: a systematic review; British Journal of Clinical Pharmacology; (2012) DOI:10.1111/j.1365-2125.2012.04220.x

[15] Medication Guidelines; . College and Association of Registered Nurses of Alberta, , (2015). http://www.nurses.ab.ca 
[16] Abdulhalim M. Mzale; Incidence and types of medication errors in the management of inpatients with chronic cardiac failure at muhimbili national hospital dar-es-salam.(2012)

[17] Guideline on medication error reporting in Ministry of Health Malaysia; ; The Pharmaceutical Services Division.(2009) Westbrook J, Woods A, Rob MI, Dunsmuir WTM, Day R. Association of interruptions with increased risk and severity of medication administration errors. Archives of Internal Medicine (2010);170: 683-90

[18] Colligan, L., \& Bass, E. J. . Interruption handling strategies during pediatric medication administration. British Medical Journal of Quality \& Safety, 21(11) (2012), 912-917. doi:10.1136/bmjqs-2011-000292

[19] Manias E, Williams A, Liew D. Interventions to reduce medication errors in adult intensive care: a systematic review ; British Journal of Clinical Pharmacology. 74(3) (2012):411-23.

[20] Richard N. Keers, Steven D. Williams, Jonathan Cooke, and Darren M. Ashcroft, Causes of Medication Administration Errors in Hospitals: a Systematic Review of Quantitative and Qualitative Evidence. Drug Saf.; 36(11) (2013): 1045-1067.

[21] ASHP Guidelines on Preventing Medication Errors in Hospitals; Medication Misadventures-Guidelines (2014)

[22] Malcolm Elliott, Yisi Liuand; The nine rights of medication administration: an overview; British Journal of Nursing, 19 (5) (2010)

[23] K Satku \& Ang Hui Gek ; Patient safety ; practice guideline tools; Ministry of health and pharmacy board Singapore.(2006)

[24] Cintia Monteiro, Ariane Ferreira, Machado Avelar and Mavilde da Luz Gonçalves Pedreira. Interruptions of nurses' activities and patient safety: an integrative literature review. Rev. Latino-Am. Enfermagem. 23(1) (2015):169-179.

[25] Hardmeier, A., Tsourounis, C., Moore, M., Abbott, W.E., \& Guglielmo, B.J.. Pediatric medication administration errors and workflow following implementation of a bar code medication administration system; . Journal for Healthcare Quality, 36(4) (2014), 54-63.

[26] Tomieto M, Sartor A, Mazzocoli E, Palese A. Paradoxical effects of a hospital-based, multiintervention programme aimed at reducing medication round interruptions. J Nurs Manag.;20(3) (2012):335-43.

[27] Fore AM, Sculli GL, Albee D, Neily J. Improving patient safety using the sterile cockpit principle during medication administration: a collaborative, unit-based project.; J Nurs Manag. 21(1) (2013):106-111

[28] Relihan E, O'Brien V, O'Hara S, Silke B. The impact of a set of interventions to reduce interruptions and distraction to nurses during medication administration.; BMJ Qual Saf ( 2010) ;19: doi:10.1136/qshc.2009.036871.

[29] Clark GJ. Strategies for preventing distractions and interruptions in the OR.; AORN J. ;97(6) (2013):702-7. 34

[30] Buchini S, Quattrin R.; Avoidable interruptions during drug administration in an intensive rehabilitation ward: improvement project. J Nurs Manag.;20(3) (2012):326- 34

[31] Jill Klingner; Shailendra Prasad; Evidence-Based Medication Safety Quality Improvement Programs and Strategies for Critical Access Hospitals Flex Monitoring Team with funding from the Federal Office of Rural Health Policy (PHS Grant No. U27RH01080. (2013)

[32] Allison Forni ,1, Hanh T. Chu2 and John Fanikos; Current Drug Safety, Bentham Science Pusblishers Ltd; Technology Utilization to Prevent Medication Errors. (2010)

[33] Baysari MT, Lehnbom EC, Westbrook JI; Bar code medication administration systems ; Evidence Briefings on Interventions to Improve Medication Safety; Centre for Health Systems and Safety Research ; Australian Institute of Health Innovation, University of New South Wales 1(1) (2013)

[34] Medication Errors ; Academy of Managed Care Pharmacy, AMCP's Framework for Quality Drug Therapy, http://www.fmcpnet.org/index.cfm?p=132D8447 (accessed February 17, (2010)

[35] Mosby's Medical Dictionary, 9th edition. (C) 2009, Elsevier.

[36] Philip J. Schneider, Bar Code Medication Administration (BCMA). Center for Medication Safety and Clinical Improvement , (2008), San Diego, CA.

[37] Canadian Society of Hospital Pharmacists, Drug Distribution: Statement on Unit-Dose \& Intravenous Admixture, (2008) www.cshp.ca

[38] National Coordinating Council for Medication Error Reporting and Prevention, Recommendations for Bar Code Labels on Pharmaceutical (Drug) Products to Reduce Medication Errors, June 5, 2007. http://www.nccmerp.org/council/council2007-0605.html (accessed February 16, 2010).

[39] Academy of Managed Care Pharmacy, AMCP's Framework for Quality Drug Therapy, Medication Errors http://www.fmcpnet.org/index.cfm?p=132D8447 (accessed February 17, )2010).

[40] Stephen Kalyniuk; Electronic Medication Management Systems — A Guide to Safe Implementation, 2nd edition, (2012). https://www.safetyandquality.gov.au/wp-content/uploads/2011/01/EMMS-A-Guide-to-Safe-Implementation-2nd-Edition-webversion.pdf

[41] Academy of Managed Care Pharmacy, Concepts in Managed Care Pharmacy Series: Drug Use Review. http://www.amcp.org/amcp.ark?p=AAAC630C (accessed March 18, 2010)Automated Medication Dispensing (2010)

[42] American Society of Consultant Pharmacists, White Paper on Automation in Pharmacy, (2013). 